\title{
PELAYANAN GEREJA KEPADA ORANG MISKIN
}

\author{
Marthen Nainupu
}

\begin{abstract}
ABSTRAKSI
Kemiskinan merupakan sebuah kenyataan atau fakta sosial dalam masyarakat manusia sejak jaman dahulu kala sampai dengan era pasca modern sekarang ini. Kemiskinan sudah dialami oleh mereka yang hidup di jaman Alkitab dan juga oleh orang percaya pada era kita ini. Boleh dikatakan bahwa kemiskinan adalah sebuah masalah abadi manusia. Dalam artikel ini fokus penulisan akan berada pada masalah kemiskinan yang bersifat material. Kemiskinan secara material merupakan sebuah tantangan yang tidak pernah habis bagi gereja. Dalam artikel ini penulis akan menyampaikan beberapa hal sebagai berikut: gambaran umum mengenai kemiskinan di Indonesia, gambaran tentang kemiskinan pada jaman Alkitab dan bagaimana mengatasinya dan selanjutnya bagaimana pelayanan gereja dapat diberikan kepada orang miskin.
\end{abstract}

Kata kunci: kemiskinan, model pelayanan kepada orang miskin.

\section{GAMBARAN UMUM TENTANG KEMISKINAN DI INDONESIA}

Kemiskinan adalah salah satu masalah utama yang dialami oleh seluruh bangsa di dunia pada segala jaman. Masalah kemiskinan masih tetap menjadi masalah terbesar dunia saat ini, sebab menyangkut masalah hidup mati seseorang. Menurut laporan dari United Nations Development Programme (UNDP) tahun 2003, terdapat 113 juta anak-anak usia sekolah, yang tidak bersekolah dan 95 persen dari mereka adalah anak-anak miskin ${ }^{1}$. Dari waktu ke waktu, masalah kemiskinan selalu membelenggu kehidupan umat manusia. Masalah kemiskinan yang terus mengancam kehidupan manusia senantiasa meningkat dari waktu

\footnotetext{
${ }^{1}$ Hartono Budi, Teologi, Pendidikan, Pembebasan (Yogyakarta: Kanisius, 2003), 23
} 
ke waktu, terutama di jaman global saat ini. Himpitan kemiskinan dan berbagai persoalan kemanusiaan lainnya terus menggiring manusia menuju suatu kehidupan tanpa harapan. Kemiskinan tidak hanya menyebabkan penderitaan yang tidak berkesudahan, tetapi juga menyebabkan kematian banyak orang sebelum waktunya.

Di Indonesia, masalah kemiskinan bukan merupakan persoalan baru. Menurut ukuran Barat, Indonesia termasuk negara berkembang atau digolongkan ke dalam sebutan "negara dunia ketiga". Negara-negara dunia ketiga khususnya Indonesia identik dengan masalah kebodohan, keterbelakangan dan kemiskinan. Mengapa Indonesia harus mendapat julukan seperti itu? Padahal kalau kita melihat luasnya wilayah Indonesia dengan kandungan alamnya yang begitu kaya, mestinya negara kita bukan tergolong negara miskin. Tapi sudahlah, kenyataannya memang demikian sejak lama. Pada jaman kolonial, pemerintahan Belanda bahkan sudah mencanangkan suatu program untuk mengatasi kemiskinan di Indonesia yang disebut "Program Politik Etis².

Sesudah Indonesia merdeka, tepatnya pada jaman Orde baru, pemerintahan Soeharto mencanangkan Repelita sebagai strategi untuk mengatasi berbagai masalah kemiskinan di Indonesia. Boleh dikatakan bahwa hasil dari setiap Repelita menunjukan perbaikan nasib dari rakyat Indonesia. Meskipun demikian, orang miskin masih saja ada di sekitar kita. Menurut Sri Bintang Pamungkas ${ }^{3}$, terdapat enam kelompok orang miskin di Indonesia. Kelompok pertama ialah mereka yang disebut fakir miskin, yaitu keluarga-keluarga dan anak-anaknya yang hidupnya terlantar. Kelompok kedua ialah mereka yang disebut kelompok informal, yaitu para pedagang asongan dan pedagang kali lima. Kelompok ketiga ialah para petani dan nelayan terutama mereka yang tinggal di pedalaman atau desa-desa. Kelompok keempat ialah para pekerja kasar yaitu para buruh tani, tukang bangunan buruh pelabuhan dan pekerja lepas. Kelompok kelima ialah kelompok pegawai negeri sipil dan $\mathrm{ABRI}$, khususnya mereka yang

\footnotetext{
2 Loekman Soetrisno, "Substansi Permasalahan Kemiskinan dan Kesenjangan" dalam Awan Setya Dewanta, Kemiskinan dan Kesenjangan di Indonesia, (Yogyakarta: Aditya Media, 1995), 17.

${ }^{3}$ Sri Bintang Pamungkas, "Kemiskinan dan Kesenjangan di Indonesia" dalam Awan Setya Dewanta, Kemiskinan dan Kesenjangan di Indonesia, (Yogyakarta: Aditya Media, 1995), 51.
} 
berada pada golongan bawah dan yang kelompok keenam ialah pengangguran termasuk para Sarjana. Dari pengelompokan menurut Sri Bintang Pamungkas, barangkali sebagian dari warga jemaat atau warga gereja adalah bagian dari kelompok-kelompok miskin tersebut.

Di era reformasi saat ini pemerintah sedang giat-giatnya melakukan berbagai proyek kemanusiaan untuk menekan angka kemiskinan di Indonesia. Meskipun demikian angka kemiskinan di Indonesia masih tetap saja tinggi. Menurut data dari Badan Pusat Statistik, angka kemiskinan di Indonesia sampai dengan tahun 2013 berada pada kisaran 28,07 juta orang miskin ${ }^{4}$ (11,37 persen) Sedangkan untuk tahun 2014, Badan Pusat Statistik melaporkan bahwa angka kemiskinan justru mengalami kenaikan dari 28,07 juta orang menjadi 28,55 juta orang. ${ }^{5}$

Kemiskinan di Indonesia lebih diperparah lagi dengan "budaya korupsi" yang sedang terjadi dan berlangsung hampir disemua lini. Pembangunan ekonomi memang berhasil menekan angka kemiskinan, tetapi jurang kesenjangan antar golongan elite dan masyarakat sederhana semakin melebar. Lihat saja di kotakota besar di Indonesia, ada banyak warga yang hidup tanpa kepastian akan hari esok, selalu takut akan penggusuran. Pembangunan menghasilkan orang-orang tersingkir serta kelompok mayoritas yang marginal.

Melihat fakta sosial seperti ini maka timbul berbagai pertanyaan dalam benak hati kita. Apa artinya kemiskinan? Apa kata Alkitab tentang hal kemiskinan ini? Apakah masalah kemiskinan masih merupakan bagian dari kepedulian gereja? Mengapa gereja perlu peduli terhadap kaum miskin? Sejauh manakah peran gereja dalam mengurangi masalah kemiskinan?

Apakah kemiskinan masih menyisahkan makna atau nilai bagi manusia? Kemiskinan adalah sebuah istilah yang sangat luas cakupannya. Sampai saat ini belum ada kesepakatan mengenai istilah tersebut. Ketika berbicara mengenai kemiskinan ada orang

\footnotetext{
${ }^{4}$ Badan Pusat Statistik, Profil Kemiskinan Di Indonesia Maret 2013, www.bps.go.id/?news=1023. Diakses tanggal 26 Juli 2014.

${ }^{5}$ Statistics Indonesia,www.bps.go.id/tab/view.php?tabel=1\&id. Diakses tgl. 5 Agustus 2014
} 
yang beranggapan bahwa itu adalah soal materi, soal sandang, pangan, papan. Ada pula yang merohanikan istilah ini yaitu miskin jiwa yaitu orang-orang yang merasa rendah diri, tidak berdaya ${ }^{6}$. Ada pula yang melihat bahwa kemiskinan pada hakekatnya adalah campur tangan yang terlalu besar dari pihak penguasa terhadap orang kecil terutama masyarakat pedesaan. Ada pula yang memandang bahwa kemiskinan pada dasarnya adalah soal kemiskinan kultural yaitu mentalitas masyarakat yang dipengaruhi oleh nilai-nilai budaya tertentu seperti nrimo, nasib dan takdir?. Belum lagi kita berbicara tentang kriteria kemiskinan, yang hingga kini belum ada kesepakatan apa yang menjadi krietria kemiskinan. Maka sebenarnya istilah kemiskinan adalah sebuah terminologi relatif, artinya dari perspektif manakah masalah kemiskinan itu mau dilihat. Dalam artikel ini saya mau melihat masalah kemiskinan dari perspektif kepedulian gereja terhadap orang yang miskin secara material. Jika kemiskinan material yang menjadi sorotan dalam tulisan ini maka pengertian kemiskinan dapat dirumuskan sebagai berikut: Kemiskinan adalah suatu kondisi dimana seseorang atau sekelompok orang tidak mampu memenuhi kebutuhan dasar / pokok hidup sebagai manusia. Kebutuhan pokok hidup selalu dimengerti sebagai kebutuhan sandang, pangan, papan dan belakang ini ditambah lagi dengan kesehatan dan pendidikan.

\section{KEMISKINAN PADA MASA ALKITAB}

Apakah kata Alkitab tentang kemiskinan? Sebagaimana penulis ungkapkan sebelumnya bahwa kemiskinan adalah salah satu masalah utama yang dialami oleh seluruh bangsa di dunia dan pada segala jaman. Itu berarti bahwa pada masa Alkitab juga sudah ada masalah kemiskinan tersebut. Orang-orang yang hidup pada masa Alkitab mereka sudah bergumul dengan soal kemiskinan. Maka berikut ini kita mencoba untuk melihat beberapa kisah tentang kemiskinan dan orang msikin pada masa Alkitab. Dalam Alkitab kita menemukan berbagai catatan atau kisah-kisah mengenai masalah kemiskinan. Di dalam kitab Kejadian, kata miskin memang tidak muncul di sana, yang ada adalah kata "kelaparan". Kisah mengenai kelaparan inipun hanya terdapat

\footnotetext{
${ }^{6}$ Malcolm B.,Tugas Manusia Dalam Dunia Milik Tuhan (Jakarta:BPK.GM.1987), 80.

${ }^{7}$ Awan Setya Dewanta, Kemiskinan dan Kesenjangan di Indonesia, (Yogyakarta: Aditya Media, 1995), 30.
} 
dalam dua bagian dalam kitab Kejadian yaitu kisah kelaparan yang terjadi pada jaman Abraham (Kejadian 12 : 10) dan kelaparan yang terjadi pada jaman Yusuf di Mesir (Kejadian $41: 27$ ). Dari kedua kisah ini penulis kitab Kejadian menggambarkan suatu keadaan yang sesungguhnya pada suatu waktu dan ini menunjuk kepada suatu fakta atau kisah-kisah nyata. Apabila Alkitab mencatat bahwa Abraham dan Yakub mengalami kelaparan, ini berarti bahaya kelaparan mengancam kehidupan semua orang pada jaman itu. Bahaya kelaparan itu sudah menggiring semua orang jatuh miskin dan hidup dalam penderitaan. Abraham maupun Yakub tergolong orang-orang yang berada pada waktu itu, namun mereka terpaksa harus mengungsi ke Mesir untuk menyelamatkan diri dari bahaya kelaparan, dapat dibayangkan bagaimana dengan mereka yang tergolong miskin pada waktu itu.

Kisah-kisah lain tentang kemiskinan tercatat dalam kitab Rut dan 2 Raja-raja. Mengenai kisah Rut kita semua tahu, tetapi rupanya kisah kemiskinan yang amat hebat terjadi di Samaria, sehingga anak manusia pun dapat menjadi makanan (2 Raja-Raja $6: 24$ - 29). Siapa saja yang tergolong kaum miskin? Di dalam Perjanjian lama terdapat beberapa kata atau istilah yang dipergunakan untuk menunjuk kepada siapa yang disebut kaum miskin.

Conrad Boerma mencatat bahwa kata pertama yang dipakai untuk menyebut mereka yang miskin ialah "ani'8 Menurut Boerma kata ini yang sering kali dipakai oleh penulis Alkitab untuk menggambarkan orang miskin. Arti harafiah dari kata ani ialah orang yang membungkuk, yang hidup dalam keadaan rendah dan dia harus memandang ke atas, bila berhadapan dengan orang yang lebih tinggi kedudukannya. Kata tersebut dipakai untuk membandingkan mereka dengan kelompok orang kaya. Maka adanya kelompok miskin adalah merupakan korban dari struktur sosial waktu itu. Kelompok kaya yang memperlakukan orang miskin sebagai orang dari kalangan rendah. Hak-hak sosial merekapun ikut berkurang. Karena mereka miskin maka mereka menjadi orang yang hina, tidak berharga dalam masyarakat orang kaya. Kemiskinan dialami sebagai suatu pemerasan terhadap hak-

\footnotetext{
${ }^{8}$ Conrad Boerma, Dapatkan Orang Kaya masuk Sorga? (Jakarta: BPK. Gunung Mulia, 1987), 11.
} 
hak hidup mereka. Dari gambaran sekilas ini kita bisa mengetahui bahwa "kemiskinan pun dalam Alkitab langsung berkaitan dengan struktur-struktur yang di dalamnya orang hidup"9. Memang harus diakui juga bahwa kemiskinan bisa juga disebabkan oleh kemalasan si miskin itu sendiri. Untuk itu kritis terhadap sifat kemalasan ini tidak jarang kita temui di dalam kitab Amsal (Amsal $10: 4,20: 13)$.

Kata lain untuk menyebut orang yang berkekurangan secara materi ialah kata "dal". Kata tersebut dipergunakan untuk menyebut mereka yang berada dalam posisi yang kurang baik seperti para buruh yang hidup di daerah pedalaman ${ }^{10}$. Selain kedua kata tersebut ada pula kata "Ebyon". Kata ini dipakai untuk menunjuk kepada mereka yang hidupnya semata-mata hanya bergantung kepada belas kasihan orang lain. Mereka ini termasuk kelompok pengemis, mereka mengemis karena keterbatasan fisik mereka seperti timpang dan lumpuh.

Di dalam Alkitab berbahasa Indonesia menggunakan beberapa kata seperti Ulangan 15:11 menggunakan kata "tertindas dan yang miskin". Amsal 10:15 juga menggunakan "kemiskinan" Amsal 22:10 menggunakan kata "orang yang lemah". Beberapa ayat dalam Perjanjian Lama menggunakan kata "kecil". Kata "kecil" sering mengacu kepada orang atau sekelompok orang yang jumlah yang sedikit. Karena itu kecil juga berarti menjadi pihak yang lemah, tersisih, mudah mendapatkan perlakuan yang tidak pantas, dihina dst. Para penulis Alkitab menggunakan beberapa istilah untuk menggambarkan apa itu kemiskinan. Ada yang menggambarkan sebagai orang yang menginginkan dan membutuhkan sesuatu. Mereka sebagai orang yang lemah tidak berdaya, orang yang terbungkuk, yang diinjak dan diperas orang lain, yang hina yang memikul beban berat ${ }^{11}$. Yang termasuk kamu miskin adalah para janda, yatim piatu dan orang asing. ${ }^{12}$ Dalam kitab Ayub 24:7-12 memberikan kepada kita sebuah gambaran

\footnotetext{
${ }^{9}$ Conrad Boerma, Dapatkan Orang Kaya masuk Sorga? (Jakarta: BPK. Gunung Mulia, 1987), 23.

10 lbid., 12.

${ }^{11}$ Malcolm, Brownlee, Tugas Manusia Dalam Dunia Milik Tuhan, (Jakarta:BPK.GM.1987), 81.

${ }^{12}$ Yosef P. Widyatmadja, Yesus \& Wong Cilik: Praksis Diakonia Transformatif dan Teologi Rakyat di Indoensia, (Jakarta: BPK. Gunung Muia, 2010), 20.
} 
yang sangat jelas mengenai keadaan orang-rang miskin. Ayub menggambarkan keadaan mereka demikian:

Dengan telanjang mereka bermalam, karena tidak ada pakaian, dan mereka tidak mempunyai selimut pada waktu dingin; oleh hujan lebat di pegunungan mereka basah kuyup, dan karena tidak ada tempat berlindung, mereka menghimpitkan badannya pada gunung batu. Ada yang merebut anak piatu dari susu ibunya dan menerima bayi orang miskin sebagai gadai. Dengan telanjang mereka berkeliaran, karena tidak ada pakain, dan dengan kelaparan mereka memikul berkas-berkas gandum; di antara dua petak kebun mereka membuat minyak, mereka menginjak-injak tempat pengirikan sambil kehausan. Dari dalam kota terdengar rintihan orang-orang yang hampir mati dan jeritan orang-orang yang menderita luka.

Para penulis Perjanjian Baru juga memberikan beberapa catatan tentang masalah kemiskinan, yang diungkapkan dalam cerita-cerita atau perumpanaan. Ada satu perumpamaan yag sangat kita kenal ialah perumpamaan tentang orang kaya dan Lazarus yang miskin. Memang ini adalah sebuah perumpamaan, tetapi perumpamaan ini tentu diangkat dari konteks sosial waktu itu. Konteks sosial waktu itu memang terdapat banyak orang miskin bahkan para pendengar khotbah Tuhan Yesus sebagian besar terdiri dari orang miskin. Tuhan Yesus sendiri menyebut diriNya sebagai orang yang tidak punya tempat tinggal tetap (Mat. 8:20). Oleh sebab itu la sangat memahami dan memperhatikan kelompokkelompok orang miskin. ${ }^{13}$ Menurut Boerma, pemberontakan orangorang Yahudi pada tahun $66 \mathrm{M}$ untuk merebut kembali Bait Allah dilakukan oleh orang-orang miskin yang sangat besar jumlahnya pada waktu itu ${ }^{14}$. Memang kita semua sadari bahwa inti dari perumpamaan ini ialah suatu ajakan kepada orang kaya untuk memperhatikan tanggung jawab sosialnya terhadap mereka yang miskin.

\footnotetext{
${ }^{13}$ Donald Guthrie, Teologi Perjanjian Baru 3. (Jakarta: BPK. Gunung Mulia, 1993), 304.

${ }^{14}$ Conrad Boerma, Dapatkan Orang Kaya masuk Sorga? (Jakarta: BPK. Gunung Mulia, 1987), 31.
} 
Di samping cerita-cerita kemiskinan, para penulis Perjanjian Baru menggunakan beberapa istilah untuk menggambarkan tentang keadaan kemiskinan pada waktu itu. Secara umum dalam Perjanjian Baru, orang-orang miskin selalu disebut sejajar atau sama dengan mereka yang sakit, yang cacat, buta, lumpuh, dan pengemis. Serangkaian kata-kata tersebut mau menggambarkan orang yang sangat miskin, orang yang tidak memiliki sesuatu apapun, yang berjuang untuk mengatasi penderitaannya demi mempertahankan hidup yang lebih lama lagi. Istilah yang paling sering dipakai untuk menggambarkan keadaan orang miskin sebagaimana disebutkan di atas ialah "Ptochos"15. Mereka yang disebut dengan sapaan ptochos, adalah mereka yang dapat dikategorikan dalam kelompok kemiskinan absolut. Kemiskinan absolut adalah "suatu kondisi dimana tingkat pendapatan seseorang tidak cukup untuk memenuhi kebutuhan pokoknya seperti pangan, sandang, papan kesehatan dan pendidikan"16 Ptochos adalah sebuah sebutan terhadap mereka yang benar-benar kekurangan, melarat sungguh dan itu sama dengan kaum pengemis.

Istilah lainnya yang dipakai oleh para penulis Perjanjian Baru untuk menyebut orang miskin ialah "penes" Namun kata penes ini menunjuk kepada mereka yang miskin namun masih sedikit mempunyai harta benda tapi mereka harus sangat menghemat dalam menggunakan harta bendanya ${ }^{17}$. Bagi mereka ini dapat digolongkan ke dalam kemiskinan relatif, dimana mereka masih memiliki sedikit harta namun jika tidak hati-hati berhemat mereka akan segera jauh ke dalam kemiskinan absolut.

Banawiratma, mendeskripsikan dengan sangat jelas kaum miskin dengan menyebutkan sebagai berikut: Kaum miskin adalah mereka yang secara sosial dikucilkan, bergantung kepada orang lain, terbuang, secara kultural mereka ditundukkan, secara fisik mereka cacat, secara psikologis tersiksa. ${ }^{18}$

\footnotetext{
${ }^{15}$ Wolfgang Stegemann, Injil dan Orang-orang Miskin (Jakarta: BPK. GM.1994), h. $2-3$.

${ }^{16}$ Heru Nugroho, "Kemiskinan, Ketimpangan dan Pemberdayaan" dalam Awan Setya Dewanta, Kemiskinan dan Kesenjangan di Indonesia, Yogyakarta: Aditya Media, 1995), 30.

${ }_{17}^{17}$ Wolfgang Stegemann, Injil dan Orang-orang Miskin, (Jakarta: BPK. GM.1994), 3.

${ }^{18} \mathrm{~J}$. B. Banawiratma, 10 Agenda Pastoral Transformatif, (Yogyakarta: Kanisius, 2002), 22 - 23
} 
Dari gambaran sekilas mengenai keberadaan orang miskin pada masa Alkitab, kita dapat melihat dan menyimpulkan bahwa dalam komunitas orang percaya pun di sana selalu terdapat pula orang-orang miskin di sekitarnya. Di sana pula komunitas orang percaya terpanggil untuk mengambil bagian dalam tanggung jawab sosial dan implementasi iman terhadap mereka yang miskin.

\section{UPAYA MENGATASI KEMISKINAN PADA MASA ALKITAB}

\section{Perjanjian Lama}

Para penulis Perjanjian Lama sejak awal sudah menaruh perhatian yang serius tentang masalah kemiskinan. Kemiskinan bukan semata-mata masalah manusia melainkan masalah Tuhan juga. Karena itu para penulis Alkitab selalu melihat bagaimana Allah selalu hadir dalam situasi keprihatinan umat manusia, khususnya terhadap umat Israel. Dalam kitab Keluaran, tercatat bahwa ketika umat Israel tertindas dan terhimpit oleh kemalangan, di sana Tuhan mendengarkan jeritan mereka. Penulis Alkitab mencatat demikian: "...Orang Israel masih mengeluh karena perbudakan dan mereka berseru-seru, sehingga teriakan mereka minta tolong karena perbudakan itu sampai kepada Allah. Allah mendengar mereka mengerang lalu la mengingat kepada perjanjianNya. Aku telah memperhatikan dengan sungguh kesengsaraan umat-Ku di tanah Mesir dan Aku telah mendengar seruan mereka yang disebabkan oleh pengerah-pengerah mereka, ya, Aku mengetahui penderitaan mereka. Sebab itu Aku telah turun untuk melepaskan mereka dari tangan orang Mesir dan menuntun mereka keluar dari negeri itu ... Sekarang seruan orang Israel telah sampai kepadaKu juga telah Ku lihat betapa kerasnya orang Mesir menindas mereka" (Keluaran 2:23,24;3:7-9)

Dari kisah tersebut kita dapat melihat bahwa Allah sendiri sangat peduli terhadap orang miskin dan yang tertindas. Kepedulian Allah terhadap orang miskin diwujudnyatakan dengan membebaskan dan membimbing sebuah umat yaitu umat Israel dari perbudakan di Mesir menuju ke tanah Kanaan. Selama perjalanan di padang gurun, Allah tetap melindungi, memelihara dengan kasih yang kekal, sehingga tepat waktunya mereka memasuki tanah perjanjian. Setelah bangsa Israel tiba di tanah Kanaan dan mereka dapat mengusahakan pertaniannya secara 
mandiri dan disana pula terjadi perubahan status ekonomi mereka. Dulunya sewaktu di Mesir mereka adalah kaum budak yang miskin dan tertindas, kini mereka mengalami suatu kemakmuran. Maka ketika mereka mempersembahkan hasil panen pertamanya, mereka merefleksikan kembali bagaimana Allah membebaskan mereka. "Ketika orang Mesir menganiaya dan menindas kami dan menyuruh kami melakukan pekerjaan yang berat, maka kami berseru kepada Tuhan, Allah nenek moyang kami lalu Tuhan mendengar suara kami dan melihat kesengsaraan dan kesukaran kami dan penindasan terhadap kami. Lalu Tuhan membawa kami keluar dari Mesir dengan tangan yang kuat dan lengan yang teracung, dengan kedahsyatan yang besar dan dengan tandatanda serta mujizat-mujizat" (UI. 24:6-9).

Bagian yang dikutip ini, bukan sekedar refleksi kembali dari suatu pengalaman semata, melainkan suatu ekspresi atau pernyataan pokok keyakinan (Kredo) ${ }^{19}$ mereka kepada Allah nenek moyang mereka. Bagi umat Israel, Allah nenek moyang mereka bukanlah suatu konsep, hasil temuan manusia, bukan pula Allah asing atau Allah yang jauh, melainkan Allah yang dekat dan yang masuk dalam pengalaman sejarah hidup mereka. Allah yang mendengarkan jeritan dan teriakan mereka. Memang ada ceritacerita bahwa allah tertentu dapat mendengarkan jeritan suatu bangsa. Namun bagi umat Israel Allah nenek moyang mereka jauh lebih berdaulat atas kehidupan. Dalam kitab Ulangan 4:33-34 Tuhan mengajukan suatu pertanyaan demikian: "Pernahkan suatu bangsa mendengar suara ilahi, yang berbicara dari tengah-tengah api, seperti yang kamu dengar dan tetap hidup? Atau pernahkah suatu allah mencoba datang untuk mengambil baginya suatu bangsa dari tengah-tengah bangsa yang lain dengan cobaancobaan, tanda-tanda serta mujizat-mujizat dan peperangan, dengan tangan yang kuat dan lengan yang teracung dan dengan kedahsyatan-kedahsyatan yang besar seperti yang dilakukan TUHAN, Allahmu, bagimu di Mesir, di depan matamu?". Dari pertanyaan ini Tuhan mau mengatakan bahwa Allah Israel adalah Allah yang hidup dan yang peduli terhadap umatNya yang tertindas. Allah yang demikian, terus berlangsung sampai dengan Tuhan Yesus Juru selamat segala bangsa datang ke dalam dunia.

${ }^{19}$ C. Barth, Theologia Perjanjian Lama 1, (Jakarta: BPK. GM. 1981), 192. 
Untuk tetap menjaga dan memelihara atau melanjutkan pemeliharaan Tuhan terhadap kaum miskin, maka Allah memberikan beberapa petunjuk yang amat konkret di dalam Hukum Taurat. Petunjuk-petunjuk itu terdapat di dalam kitab-kitab Musa. Pertama dalam Imamat 25:8-43 tentang tahun Yobel. Tahun Yobel sebagai suatu sistim tata hidup bersama dalam suatu masyarakat berdasarkan kesetaraan (Keluaran 23:9, Imamat 19:33-34). Oleh sebab itu pada tahun Yobel ditetapkan Tuhan sebagai tahun penghapusan hutang, tahun pembebasan para budak dan tahun pengembalian tanah milik orang miskin yang terjual kepada orang kaya. Tahun Yobel jatuh pada tahun kelima puluh. Rupanya tahun Yobel adalah suatu gagasan ideal untuk limapuluh tahunan.

Kedua, Keluaran 23:10-11; Imamat 25:1-7, tentang tahun Sabat. Lamanya Tahun Yobel 50 tahun. Maka bagi mereka yang berhutang atau menjual tanahnya dan para budak harus menunggu 50 tahun baru bisa mendapatkan pembebasan, rasanya cukup lama. Oleh sebab itu Tuhan memberikan tahun Sabat yang berlaku para tahun ke-7. Tahun Sabat adalah tahun pembebasan yang dilakukan pada tahun ke-7. Tujuan dari pembebasan adalah "untuk menolong orang miskin, tanah, dan binatang dari perlakuan yang tidak adil oleh kebijakan ekonomi saat itu"20

Selain Tahun Yobel dan tahun Sabat, Tuhan menempatkan pula suatu waktu yang lebih pendek yaitu setiap tahun dengan peraturan perpuluhan (Ulangan 14:22-29). Perpuluhan adalah persembahan dari hasil bumi, ternak setiap tahun dan berkalu bagi semua orang Israel. Perpuluhan diperuntukan bagi orang Lewi, karena mereka tidak memiliki warisan tanah. Tetapi perpuluhan tidak hanya untuk orang Lewi melainkan juga untuk memelihara orang miskin, yatim piatu dan orang asing. ${ }^{21}$

Dari apa yang kita lihat di atas tampak dengan sangat jelas, adanya suatu struktur penataan kehidupan sosial yang amat bagus. Dari konsep tahun Yobel, 50 tahunan dijabarkan lagi ke dalam tahun Sabat, 7 tahunan dan lebih operasional lagi dalam hal perpuluhan yang berlangsung setiap tahun. Dengan demikian perhatian dan tanggung jawab sosial terhadap orang miskin tidak

\footnotetext{
${ }^{20}$ Yosef P. Widyatmadja, Yesus \& Wong Cilik: Praksis Diakonia Transformatif dan Teologi Rakyat di Indoensia, (Jakarta: BPK. Gunung Muia, 2010), 22.

${ }^{21}$ Widyatmadja, Yesus \& Wong Cilik, 23.
} 
akan pernah terabaikan, melainkan akan terus berlanjut dari setiap tahun menuju 7 tahun dan 50 tahun sebagai perayaan pembebasan akbar bagi orang miskin, yatim piatu dan orang asing.

Rupanya pada awalnya pelaksanaan tahun Yobel, tahun Sabat dan perpuluhan dapat dijalankan dengan baik oleh orang Israel sebagai upaya untuk terus memelihara dan mencukupkan kebutuhan orang-orang miskin. Akan tetapi dalam perjalan sejarah Israel yang panjang, sampai pada jaman para nabi terutama jaman Yesaya, Amos, dam Mikha, pelaksanaan hukum Tourat khususnya mengenai pemeliharaan dan tanggung jawab sosial terhadap mereka yang miskin mulai terabaikan. Bukan hanya itu saja, tetapi rupanya ada suatu usaha yang terencana yang dilakukan oleh penguasa dan kaum kaya di Israel untuk menindas dan merampas hak-hak hidup orang miskin. Karena itu, baik nabi Yesaya, Amos dan Mikha mulai melakukan kritis-kritis sosial terhadap kehidupan penguasa dan kelompok kaya yang melalui kebijakan-kebijakan mereka telah memperkosa dan merampas hak-hak hidup orang kecil. Kritik-kritik ini sebagai usaha untuk menegakkan hukumhukum Tuhan di tengah kehidupan umat Israel.

\section{Perjanjian Baru}

Di dalam Perjanjian Baru, kita menemukan juga perhatian dan kepedulian terhadap orang miskin. Ketika Tuhan Yesus di dunia ini la juga sangat dekat dengan mereka yang tersisih, tertolak dan terbuang. Apabila kita membaca kitab-kitab Injil sinoptik, cukup jelas bagi kita bagaimana Tuhan Yesus sangat peduli terhadap mereka yang tertolak. Dalam Lukas 17:11-19 Lukas mencatat sebuah peristiwa di mana Tuhan Yesus dalam perjalanannya ke Yerusalem, ia memilih untuk menyusur daerah perbatasan Samaria dan Galilea. Rupanya daerah perbatasan atau daerah pinggiran ini adalah tempat pembuangan orang-orang kusta. Daerah seperti itu yang dipilih oleh Tuhan Yesus dan benar juga bahwa di sana Tuhan Yesus bertemu dengan sepuluh orang kusta. Nampak dengan jelas bahwa Tuhan Yesus dalam mewujudkan karya keselamatan-Nya, la mengarahkan perhatian-Nya kepada kelompok-kelompok pinggiran. Penulis Injil Lukas, menempatkan pemberitaan kabar baik bagi mereka yang miskin di awal pelayanan Tuhan Yesus (Lukas 4:18-19). Tak dapat disangkal bahwa Tuhan Yesus memusatkan perhatian-Nya pada kelompok 
paling lemah dalam masyarakat waktu itu. Memang sewaktu-waktu la berada di bait Allah pada hari Sabat. Tetapi la menghabiskan sebagian besar waktu-Nya dengan berkeliling dari kampung ke kampung, dari kota ke kota untuk menjumpai mereka yang paling miskin dan lemah secara materi dalam masyarakat waktu itu.

Mengapa Tuhan Yesus begitu peduli dengan orang-orang lemah dan orang-orang miskin? Dengan jujur kita harus katakan bahwa kita atau tak seorang pun tahu alasan Tuhan Yesus mengapa la berpihak kepada orang miskin dan lemah. Namun demikian dari berbagai sumber dari Alkitab kita bisa mengetahui sedikit tentang alasan Tuhan peduli terhadap mereka yang lemah.

Menurut kesaksian Alkitab, manusia diciptakan menurut gambar dan rupa Allah (Kej. 1:26). Oleh karena itu siapa pun dan apa pun statusnya, gambar dan rupa Allah ada padanya. Itulah sebabnya ketika Tuhan Yesus tampil di Nasaret pada hari Sabat la membacakan dari kitab nabi Yesaya demikian: "Roh Tuhan ada pada-Ku...untuk menyampaikan kabar baik kepada orang-orang miskin ... untuk memberitakan pembebasan kepada orang-orang tertawan dan penglihatan kepada orang-orang buta, untuk membebaskan orang-orang yang tertindas" (Lukas 4:8-19). Pada kesempatan lain ketika Tuhan Yesus menyampaikan kotbah-Nya di atas bukit la menempatkan orang-orang miskin dalam suatu perhatian khusus, la berkata: "Berbahagialah, orang yg miskin di hadapan Allah, karena merekalah yang empunya kerajaan Sorga" (Matius $5: 3$ ).

Sepanjang sejarah gereja, memang terdapat pemahamam yang berbeda-beda mengenai ungkapan Tuhan Yesus. "Berbahagialah orang yang miskin .... karena merekalah yang empunya kerajaan Sorga" sehingga ada golongan yang sangat menekankan soal kemiskinan sebagai suatu usaha kesalehan. Pada pihak lain ada yang memahaminya secara dualistis artinya bahwa gereja cukup menangani hal-hal rohani saja dan aspekaspek sosial bukanlah merupakan tanggung jawab gereja. Pemahaman yang demikian tentu akan sangat mempersempit ruang pelayanan dan kesaksian gereja. 


\section{Miskin Bukan Sebuah Cita-Cita}

Sebagaimana disebut di atas bahwa ada kelompok tertentu yg memahami kata-kata Tuhan Yesus dalam Matius 5:3 sebagai suatu usaha/cita-cita kesalehan. Memang ada ayat ayat tertentu di dalam Alkitab yang cenderung untuk ditafsirkan sebagai dasar bagi pandangan tersebut. bahwa Allah menginginkan manusia menjadi miskin. Misalnya 1 Samuel 2:7. Namun di dalam I Samuel 2:7 tidak dikatakan bahwa Allah menjadikan atau menetapkan orang untuk kaya atau miskin, sehingga kemiskinan selalu dan hanya disebabkan oleh Allah. Tuhan membuat miskin dan membuat kaya, hal itu menunjuk pada kuasa Allah dan bukan suatu derajat kesewenang-wenangan Allah, yang menjadikan manusia kaya atau miskin.

Kata Yunani "ptochos" mau menggambarkan orang miskin dan yang menderita akibat keadaan keadaan mereka, namun yang di dalam kemiskinannya membuat dirinya bergantung kepada Allah, orang-orang seperti itu yang pengharapannya ditujukan hanya kepada Allah disebut "berbahagia". Karena itulah menurut saya, Tuhan Yesus tidak setuju dengan kemiskinan sebaliknya la mengalahkan kemiskinan. Allah tidak mengagungkan kemiskinan tapi la mengubah kemiskinan (Mat. 11:4-5).

Dalam Kisah Para Rasul 2:44-45, diceritakan bahwa "segala kepunyaan mereka adalah, kepunyaan bersama dan selalu ada dari mereka yang menjual harta miliknya. Hal ini tidak bermaksud bahwa gereja mula mula ingin membangun suatu persekutuan orang-orang miskin. Yang mau diungkapkan dalam ayat-ayat itu ialah semangat persaudaraan sehingga tidak ada seorangpun yang berkekurangan diantara mereka. (Kis. 4:34). Jadi kalau ada anggota yang menjual miliknya dan membagi-bagikannya di antara mereka, hal ini tidak di lakukan supaya mereka menjadi miskin tetapi agar tidak ada orang miskin di antara mereka. Inilah wujud gereja mula-mula, yang cinta kepada orang orang miskin dan bukan cinta akan kemiskinan.

\section{Miskin Bukan Nasib}

Sekiranya semua yang terjadi dalam hidup manusia sudah ditakdirkan sebelumnya oleh Allah dan karena itu tidak ada lagi 
alasan untuk mencari kelepasan dari penderitaan, maka kemungkinan besar Tuhan Yesus tidak akan datang ke dunia ini dan sebab itu la tidak bisa mengubah apa yang sudah menjadi nasib orang kecil dan itu berarti tidak ada pengharapan bagi orang kecil. Akan tetapi ketika Tuhan Yesus datang kepada orang orang miskin (buta, timpang, tuli,dll.) la menyerukan "Berbahagialah". Selanjutnya disusul dengan tindakan pembebasan yang buta dapat melihat yang timpang dapat berjalan dan yang tuli bisa mendengar. Tuhan Yesus tidak berkata untunglah kamu orang-orang miskin karena kamu dicintai Allah, karena itu terimalah nasibmu dan nantikanlah kebahagiaan itu di Sorga nanti. Pola pikir seperti disebutkan di atas adalah pola pikir fatalistis yang membentuk sikap skeptis. Dengan demikian orang lebih cenderung menerima situasi tertentu sebagai mana adanya tanpa mengusahakan perubahan dan pembaharuan. Apakah hal yang demikian yang dimaksudkan oleh Tuhan Yesus? Tentu bukan. Yang ingin dikatakan oleh Tuhan Yesus "Berbahagialah kamu orang miskin ,mulai sekarang kamu, tidak miskin lagi, sengsaramu telah berakhir, kerajaan Allah sudah datang. Dari sini kebahagiaan itu merupakan wujud keselamatan. Tindakan nyata Allah dalam konteks dan situasi konkret. Kabar kesukaan tidak lagi sematamata pemberitaan firman, melainkan perbuatan nyata seperti yang nampak dari tindakan-tindakan Tuhan Yesus kepada orang miskin dan yang lemah.

Memang harus diakui bahwa pokok pelayanan Tuhan Yesus adalah pewartaan kabar baik, Injil kerajaan Allah. Dan injil itu sebagai daya kekuatan Allah yang dinamis sehingga kaum miskin diajak untuk menyadari kekuatan Allah itu di antara diri mereka. Kerajaan Allah berarti kekuatan atau daya baru untuk berjuang secara terus menerus. Dengan demikian di dalam dan oleh Tuhan Yesus yang mewartakan Injil Kerajaan Allah itu, ada harapanharapan baru bagi kaum miskin dan yang tertindas untuk melakukan tindakan-tindakan pembaharuan hidup dan memperbaiki keadaan-keadaan mereka. Karena itu kepada mereka diundang atau disampaikan ucapan selamat berbahagia.

Perhatian terhadap orang miskin dilanjutkan oleh murid-murid Tuhan Yesus dan pada rasul terutama oleh rasul Paulus. Dalam catatan Kisah Para Rasul tercatat bahwa mereka yang percaya kepada Tuhan Yesus hidup dalam persekutuan dan di antara 
mereka ada yang menjual harta miliknya dan membagikan kepada sesamanya yang miskin agar tidak ada orang miskin di antara mereka. Sikap kebersamaan dan kepedulian di antara orang percaya pada waktu itu merupakan suatu ciri yang khas dari praktik kehidupan jemaat mula-mula Dalam perjalanan dan pelayanan Rasul Paulus dalam memberitakan injil dan kabar baik, ia juga memberi nasehat agar anggota jemaat saling tolong menolong dalam segala. Dalam surat Paulus kepada jemaat di Korintus, ia menyampaikan petunjuk-petunjuk praktik tentang bagaimana membantu sesama yang miskin (I Kor.16:1-4). Petunjuk itu sungguh-sungguh dipraktikan oleh jemaat Makedonia dan Akhaya yaitu pada waktu terjadi kelaparan di Yerusalem, mereka mengumpulkan sejumlah bantuan kepada jemaat Yerusalem melalui rasul Paulus (Roma 15:25-27). Kepedulian dan bantuan kepada sesama orang percaya yang berada di dalam kekurangan, hal ini dilakukan bukan sebagai suatu usaha untuk memberikan legitimasi terhadap kedudukan mereka yang miskin melainkan sebagai suatu tindakan iman agar ada keseimbangan di antara mereka. (II Kor. 8:13-14)

Dari beberapa penjelasan di atas, kita dapat melihat bahwa sejak jaman Alkitab, Tuhan Allah sendiri sangat menaruh peduli terhadap orang miskin. Tuhan memberikan pedoman-pedoman bagaimana membantu mereka yang miskin. Kepedulian dan bantuan kepada mereka yang lemah selanjutnya diteruskan oleh para nabi sampai dengan Tuhan Yesus. Selanjutnya tugas kemanusiaan diteruskan oleh para rasul.

\section{PELAYANAN KEPADA ORANG MISKIN}

Menurut tradisi, gereja hadir di tengah dunia ini dengan mengemban tiga tugas utama yaitu "Koinonia, Marturia dan Diakonia" (bersekutu, bersaksi dan melayani). Dari ketiga tugas pokok ini kemudian dijabarkan lebih lanjut lagi ke dalam keseluruhan tugas dan pelayanan gereja di dunia. Rumusan ketiga tugas utama tersebut tentu mengalami suatu proses yang panjang, namun paling tidak rumusan tugas utama tersebut telah diinspirasi dari laporan penginjil Matius tentang pelayanan Tuhan Yesus. Matius melaporkan bahwa pelayanan Tuhan Yesus selama di dunia ini menyentuh tiga bidang utama seperti yang tertulis demikian: "Yesus pun berkeliling di seluruh Galilea, la mengajar 
dalam rumah-rumah ibadat dan memberitakan Injil Kerajaan Allah serta melenyapkan segala penyakit dan kelemahan di antara bangsa itu" (Matius 4:23). Selanjutnya dikatakan demikian: "Demikianlah Yesus berkeliling ke semua kota dan desa, la mengajar dalam rumah-rumah ibadat, dan memberitakan Injil Kerajaan Sorga serta melenyapkan segala penyakit dan kelemahan" (Matius 9: 35).

Mengajar, dapat kita pahami sebagai upaya untuk membangun dan membentuk moral, karakter dan iman orang percaya. Hal ini kita dapat pahami mengingat situasi sosial pada jaman Tuhan Yesus yang penuh dengan konflik, pertentangan bahkan perang di wilayah Palestina. Dalam situasi yang demikian, tentu setiap orang memanggul senjata untuk mempertahankan diri dan hidupnya. Jika demikian, maka hukum yang berlaku ialah hukum rimba raya siapa kuat dialah yang menang. Semangat seperti itulah yang sedang tumbuh kuat di dalam diri orang Israel yang notabene mereka adalah umat yang mengenal Allah sejak lama, tetapi praktek hidup dalam keseharian tidak selalu sama dengan pengenalannya akan Allah. Di sinilah Tuhan Yesus hadir di bait Allah setiap hari Sabat lalu mengajar di sana.

Pada saat yang sama Tuhan Yesus juga memberitakan Injil Kerajaan Sorga. Pemberitaan injil dapat kita pahami sebagai upaya Tuhan Yesus untuk menuntun seluruh bangsa kepada keselamatan melalui iman kepadaNya. Memberitakan injil sebagai panggilan keselamatan yang ditujukan kepada setiap orang pada jaman itu. Pada jaman itu boleh dikatakan bahwa Palestina merupakan pusat keagamaan, peradaban, pusat ekomoni dan politik, sehingga berkumpul banyak bangsa di sana dan di situlah Tuhan Yesus hadir serta memberitakan Injil kerajaan Allah berdasarkan pengampunan dosa dan melalui iman Tuhan Yesus sendiri.

Melenyapkan segala kelemahan, dapat kita pahami sebagai kepedulian Tuhan Yesus terhadap mereka yang terbelenggu oleh berbagai ikatan kehidupan, seperti sakit penyakit, penindasan dan himpitan kemiskinan. Maka kehadiran Tuhan Yesus adalah kehadiran yang memberi kelepasan terhadap mereka yang tersisih dan terbuang. Dari gambaran singkat ini saya melihat bahwa pelayanan Tuhan Yesus menyentuh keseluruhan dari kebutuhan 
pokok manusia yaitu masalah moral, keselamatan dan kehidupan jasmani. Pelayanan yang utuh menyeluruh.

Sejak hadimya gereja di dunia, ia sudah berkomitmen untuk meneruskan karya pelayanan yang sudah dibangun oleh Tuhan Yesus yang dirumuskan oleh gereja sebagai "tri tugas gereja". Dari ketiga tugas pokok tersebut, rupanya perhatian gereja kepada tugas pokok yang ketiga yaitu pelayanan kepada mereka yang lemah dan miskin masih kurang mendapatkan perhatian yang penuh. Ini menurut dugaan saya, sebab kalau saya melihat program dan anggaran dari beberapa gereja untuk pelayanan bagi orang miskin hampir-hampir tidak terlihat dengan jelas. Kalaupun ada itu hanya bersifat sesaat saja. Barangkali kita perlu catat bahwa hanya gereja Katolik saja yang mempunyai kepedulian yang cukup besar untuk melayani orang miskin. Memang perlu diakui bahwa pelayanan penggembalaan yang lebih banyak diperhatikan ialah pelayanan mimbar atau bidang rohani. Pelayanan penggembalaan lebih diwarnai oleh gerak ibadah dan itu berpusat di dalam gedung gereja seperti natal, paskah dan hari-hari ibadah lainnya. Gereja masih bergerak pada apa yang biasa terjadi, gereja masih terpaku pada rutinitas yang berpusat pada ibadah di dalam gedung gereja. Gereja perlu memikirkan pelayanan yang bersifat holistik yang tertuang dalam suatu pedoman penggembalaan yang lebih lengkap yang di dalamnya memuat arahan pelayanan kepada orang miskin.

Memang kita sadari bahwa fungsi pelayanan dan penggembalaan adalah sangat luas cakupannya yang meliputi lima bidang pelayanan yaitu "penyembuhan, penopangan, bimbingan, pendamaian, dan memberi makan/pendidikan"22. Dan memang hingga saat ini gereja sudah melakukan sebagian dari kepeduliannya terhadap orang miskin. Kepedulian itu dapat kita lihat dan kenal dengan tiga model pelayanan kepada mereka yang miskin. Model pertama dan yang sangat tua atau tradisional yang dilakukan oleh gereja ialah model Karitatif ${ }^{23}$. Bentuk pelayanan kepada mereka yang miskin dengan model karitatif dibangun dari pemahaman tradisional gereja, terutama pada tindakan-tindakan amal sesuai dengan Matius 25:31-46. Ayat-ayat ini dipakai oleh

\footnotetext{
${ }^{22}$ Howard Clinebell, Basic Types of Pastoral Care and Counseling (Nashville: Abingdon Press, 1984), 43.

${ }^{23}$ Widyatmadja, Yesus \& Wong Cilik, 31.
} 
gereja untuk menguraikan bentuk pelayanan. Sampai dengan saat ini, pelayanan kepada orang miskin dengan model karitatif ini sangat populer di kalangan gereja. Seperti yang seringkali kita lakukan, menjelang Natal, gereja melakukan aksi sosial atau amal sosial. Pertimbangan dari model ini ialah bahwa mereka yang ditolong itu merasakan langsung bantuan tersebut dan berlangsung saat itu juga sehingga tidak ada beban untuk selanjutnya. Belakangan ini model pelayanan karitatif mulai dikritik dan dievaluasi. Semakin disadari bahwa dengan model karitatif, kedudukan orang miskin semakin mendapatkan legitimasi dan mereka dijadikan objek kebajikan dari mereka yang hidupnya lebih baik secara materi. "Pelayanan dengan model karitatif menghasilkan ketergantungan dan status quo" ${ }^{24}$. Dari kritik dan evaluasi terhadap model karitatif, lalu memunculkan model kedua yaitu model Reformatif.

Model kedua ialah model Reformatif ${ }^{25}$. Menurut Widyatmadja, model reformatif dapat disebut juga sebagai model pembangunan. Model ini tidak murni lahir dari refleksi gereja terhadap kemiskinan melainkan muncul dari perjuangan Perserikatan Bangsa-Bangsa (PBB) untuk mengatasi kesenjangan dan kemiskinan antara blok utara dan selatan. Ide cemerlang ini kemudian ditangkap oleh Dewan Gereja Dunia (DGD) dan mengalir ke Dewan Gereja-Gereja Indonesia (DGI) yang saat ini sudah berganti nama menjadi Persekutuan Gereja-Gereja Indonesia (PGI) Dari sinilah mulai bergeser dari model karitatif ke model reformatif atau model pembangunan. Ada sedikit kemajuan dengan model ini yaitu tidak sekedar berbuat amal atau membagi makanan, minuman dan pakaian kepada orang miskin melainkan kepada mereka diperlengkapi dengan beberapa ketrampilan tertentu untuk dapat hidup secara mandiri, tidak lagi bergantung kepada uluran tangan orang lain. Dari model ini kita kenal beberapa gereja yang memberikan kursus ketrampilan, bagi warganya agar mereka bisa bekerja dan tidak menggantungkan nasibnya kepada kebajikan orang lain. Dalam perjalannya model inipun tidak lepas dari kritik dan evaluasi, karena disadari bahwa mereka yang memiliki ketrampilan dengan baik tetapi sumber penyebab kemiskinan belum teratasi dengan baik, misalnya sistim ekonomi dan hak-hak

\footnotetext{
24 Ibid., 34.

25 Ibid., 36.
} 
rakyat kecil masih diabaikan. Dari sini lalu muncul model yang ketiga yaitu model transformatif.

Model ketiga model transformatif ${ }^{26}$ Model transformatif ini sering juga disebut dengan nama model kontekstual. Model ini berawal dari pemahaman ulang terhadap ekklesiologi dan tri tugasnya. Gereja tidak lagi hanya diartikan gedung, melainkan "gerakan" yang terbuka bagi pembangunan dan visi kerajaan Allah. Ada ungkapan yang kita kenal bahwa gereja bisa ada tanpa gedung, tetapi tanpa pelayanan kepada mereka yang miskin gereja sudah mati. Ungkapan ini bukan pernyataan yang berlebihan, jika gereja dipahami sebagai gerakan yang bergerak keluar dan menjangkau ke semua aspek kebutuhan hidup manusia. Atas dasar pemikiran ini maka pelayanan kepada mereka yang miskin dan tersisih dimengerti sebagai pelayanan yang multi dimensial yang menyentuh roh, tubuh dan jiwa dan juga multi sektoral yang menyentuh aspek ekonomi, politik, kultural dan hukum. Model transformatif ini merupakan perjuangan-perjuangan konkret bersama mereka yang tersisih dan miskin untuk melawan penindasan struktural yang dibuat oleh kaum penindas.

Dari ketiga model pelayanan tersebut di atas tampaknya semuanya baik pada waktu dan konteks tertentu. Di sana juga terlihat bahwa ada suatu sikap kritis terhadap semua model dan oleh sebab itu selalu ditemukan pula pikiran-pikiran baru untuk terus memperbaharui bentuk-bentuk pelayanan kepada orang miskin. Model transformatif jauh lebih maju di mana keberpihakan kepada mereka yang miskin sudah dilibatkan sebagai subjek. Orang miskin bukanlah objek kebajikan dari orang yang baik hati, melainkan mereka harus dijadikan subjek dan pelaku utama dalam perubahan hidup mereka. Model transformatif terus berjuang untuk menanamkan rasa kesamaan di antara sesama umat manusia. Kedudukan orang miskin dapat diubah karena bukan nasib dan yang mempunyai kekuatan untuk mengubah adalah diri mereka sendiri ${ }^{27}$. Sudah saatnya untuk memberi pelayanan kepada orang miskin dengan melibatkan mereka sebagai subjek dalam membuat kebijakan.

\footnotetext{
${ }^{26}$ Widyatmadja, Yesus \& Wong Cilik, 43.

${ }^{27}$ Heru Nugroho, "Kemiskinan, Ketimpangan dan Pemberdayaan" dalam Awan Setya Dewanta, Kemiskinan dan Kesenjangan di Indonesia, (Yogyakarta: Aditya Media, 1995), 35.
} 


\section{BAGAIMANA MENGELOLA PELAYANAN KEPADA ORANG MISKIN}

Pelayanan kepada orang miskin memang sudah dilakukan oleh gereja, baik dengan model karitatif, reformatif maupun transformatif, meskipun harus diakui bahwa belum sepenuhnya. Pelayanan kepada mereka yang lemah dan miskin belum mendapatkan upaya-upaya antisipatif atau kurang memiliki perencanaan yang jelas. Dengan demikian maka amat sulit juga untuk mengajukan pertanyaan-pertanyaan kritis seperti pernahkah diadakan evaluasi. Sejauh mana sudah cukup merata dan menjangkau semua warga gereja yang termasuk kategori miskin? Sejauh mana frekuensinya teratur dan memadai, berkesinambungan dan bertahap? Sejauh mana bermutu, mengena dan efektif? Sejauh mana semua warga jemaat melibatkan diri secara aktif dalam pelayanan ini? Pertanyaan-pertanyaan evaluatif semacam ini sangat penting untuk bisa melihat tingkat kepedulian kita kepada mereka yang miskin. Jawaban terhadap berbagai pertanyaan di atas, hanya mungkin dapat terjawab secara benar dan tepat bila mana gereja mempunyai perencanaan yang jelas dengan data yang pasti, secara tertulis yang dapat dijadikan bahan evaluasi. Data yang tersimpan dalam bentuk tulisan itu dapat dijadikan arahan kerja. Artinya pelaksanaan pelayanan itu tidak boleh ngawur tanpa gambaran yang jelas mau apa, melainkan bekerja menurut arah yang dituju atau yang ingin dicapai. Jalan yang ditempuh untuk mencapai tujuan itu. Langkah-langkah dalam menyelesaikan tugas besar itu secara bertahap dan berkesinambungan. Data semacam itu perlu disusun secara sitimatis artinya mengikuti suatu alur pikir yang jelas dan konkret dan yang nanti bermuara pada sasaran akhir.

Pelayanan kepada orang miskin harus berbasis data, artinya bahwa gereja harus mempunyai data mengenai pemetaan wilayah kantong-kantong kemiskinan. Gereja perlu mempunyai data tentang potensi diri gereja. Pelayanan hanya dapat menanggapi kebutuhan dan harapan orang miskin secara tepat, mengena dan efisien bila berpangkal pada realitas kebutuhan warga yang berada di dalam kategori miskin. Maka realitas kebutuhan harus dikenal dengan baik dan tepat. Di sini diperlukan matriks kebutuhan, masalah, potensi dan kesanggupan (Lukas 14:28-32). 
Selain masalah perencanaan yang belum bersifat antisipatif, masalah lain yang kita jumpai dalam pelayanan kepada orang miskin ialah bahwa pelayanan kepada orang miskin sudah dikerjakan tetapi pelayan itu berjalan sendiri-sendiri, belum adanya suatu koordinasi yang baik dan terpadu. Semua warga gereja belum diikut sertakan dalam keprihatian ini. Untuk masalah ini maka gereja perlu membuat keputusan pastoral atau kebijakan kepedulian kepada orang miskin yang bersifat mengikat semua bagian pelayan kepada orang miskin. Dengan demikian masingmasing bagian tidak bekerja sendiri-sendiri. Kita sadari bahwa gereja sebagai kelompok minoritas, maka perlu menyatukan semangat dan daya kerja yang kuat. Sebab gereja sebagai kawanan kelompok kecil hanya akan memberikan kontribusi yang berarti bagi masyarakat luas dan khususnya orang miskin apabila pastisipasinya memiliki daya yang besar dan mutu tinggi, dan hal itu hanya di dapat di dalam kebersamaan. (Pengkhotbah 4:9-12, Lukas 11:17). Penyatuan kekuatan atau kebersamaan inipun harus melibatkan orang miskin itu sendiri (lihat pembahasan sebelum ini). Bila perlu kelompok orang miskin itu sendiri dimotivasi dan diorganisir oleh gereja untuk membuat lembaga pemberdayaan mandiri, agar orang-orang miskin bersatu dalam suatu organisasi. Sebab ketika mereka bersatu akan memunculkan solidaritas dan perasaan identitas yang sama sekaligus memberikan harapan yang kuat untuk bergerak maju bersama-sama sehingga mereka dapat melepaskan diri sifat-sifat budaya kemiskinan ${ }^{28}$. Selain pemberdayaan orang miskin melalui organisasi mandiri, pada saat yang sama, perlu untuk membangkitkan keyakinan dari diri orang miskin itu sendiri bahwa kekuatan yang paling besar untuk melakukan perubahan itu ada pada mereka. Apabila telah timbul keyakinan tersebut maka hambatan-hambatan akan dapat dengan mudah teratasi.

\section{PENUTUP}

Masalah paling pelik dan paling tua yang tak mudah diselesaikan secara tuntas adalah masalah kemiskinan, sebagaimana yang kita simak dari pengalaman pada jaman Alkitab (jaman kuno) dan sampai dengan era yang kita sebut sebagai era paska modenr

\footnotetext{
${ }^{28}$ Djamaludin Ancok, "Pemanfaat organisasi lokal untuk mengentaskan Kemiskinan" dalam Awan Setya Dewanta, Kemiskinan dan Kesenjangan di Indonesia, (Yogyakarta: Aditya Media, 1995), 166.
} 
inipun masalah kemiskinan belum dapat terselesaikan dengan tuntas. Berbagai kebijakan dan program baik dari pemerintah maupun gereja sudah dilakukan, tetapi masalah orang miskin masih tetap saja ada di antara kita. Meskipun demikian, gereja tidak pernah berhenti dari upaya-upaya menolong dan melayani orang-orang miskin. Di sinilah gereja hadir dalam upaya untuk menolong dan memberdayakan orang miskin. Upaya gereja untuk menolong orang miskin sudah dilakukan dengan berbagai model, mulai dari model karitatif yang sangat tradisional, reformatif maupun transformatif.

Upaya-upaya untuk menolong orang miskin akan dapat dilakukan dengan lebih baik dan sungguh-sungguh memberdayakan mereka ialah dengan mengikut sertakan mereka sebagai subjek sebab mereka sendiri merupakan suatu kekuatan yang besar untuk melakukan perubahan untuk memperbaiki keadaan mereka. Di samping itu pelayanan gereja kepada orang miskin harus berbasis pada data, terutama data mengenai potensi atau kekuatankekuatan gereja serta melakukan suatu koordinasi yang baik dan terpadu agar semua warga gereja diikut sertakan dalam keprihatian ini. Untuk maksud tersebut maka gereja perlu membuat keputusan pastoral atau kebijakan kepedulian kepada oang miskin yang dapat dijadikan panduan bagi semua bagian pelayanan dari gereja.

\section{DAFTAR KEPUSTAKAAN}

Ancok, Djamaludin. "Pemanfaat organisasi lokal untuk mengentaskan Kemiskinan" dalam Awan Setya Dewanta, Kemiskinan dan Kesenjangan di Indonesia, (Yogyakarta: Aditya Media, 1995)

Badan Pusat Statistik, Profil kemiskinan di Indonesia maret 2013, www.bps.go.id/?news=1023. Diakses tanggal 26 Juli 2014.

Banawiratma, J.B. 10 Agenda Pastoral Transformatif, (Yogyakarta: Kanisius, 2002)

Barth, C. Theologia Perjanjian Lama 1, (Jakarta: BPK. GM. 1981)

Boerma, Conrad. Dapatkan Orang Kaya Masuk Sorga? (Jakarta: BPK. Gunung Mulia, 1987) 
Brownlee, Malcolm. Tugas Manusia Dalam Dunia Milik Tuhan, (Jakarta: BPK. GM. 1987)

Budi, Hartono.Teologi, Pendidikan, Pembebasan, (Yogyakarta: Kanisius, 2003,)

Clinebell, Howard. Basic Types of Pastoral Care and Counseling, (Nashville: Abingdon Press, 1984)

Dewanta, Awan Setya. Kemiskinan dan Kesenjangan di Indonesia, (Yogyakarta: Aditya Media, 1995)

Guthrie, Donald. Teologi Perjanjian Baru 3. (Jakarta: BPK. Gunung Mulia, 1993)

Nugroho, Heru. "Kemiskinan, Ketimpangan dan Pemberdayaan" dalam Awan Setya Dewanta, Kemiskinan dan Kesenjangan di Indonesia, Yogyakarta: Aditya Media, 1995)

Pamungkas, Sri Bintang. "Kemiskinan dan Kesenjangan di Indonesia" dalam Awan Setya Dewanta, Kemiskinan dan Kesenjangan di Indonesia, (Yogyakarta: Aditya Media, 1995)

Soetrisno, Loekman. "Substansi Permasalahan Kemiskinan dan Kesenjangan" dalam Awan Setya Dewanta, Kemiskinan dan Kesenjangan di Indonesia, (Yogyakarta: Aditya Media, 1995)

Statistics Indonesia, www.bps.go.id/tab/view.php?tabel=1\&id. Diakses tanggal 5 Agustus 2014

Stegemann, Wolfgang. Injil dan Orang-orang Miskin, (Jakarta: BPK. GM. 1994)

Widyatmadja, Yosef P. Yesus \& Wong Cilik: Praksis Diakonia Transformatif dan Teologi Rakyat di Indonesia, (Jakarta: BPK. Gunung Mulia, 2010) 